\title{
New Migrants from Continental China in Philippine Cities: Differences in Profiles and Settlements
}

Les nouveaux migrants de Chine continentale dans les villes philippines : profils et ancrages différenciés

Los nuevos migrantes de la China continental en las ciudades filipinas:

diversidad de perfiles y asentamientos

\section{Catherine Guéguen}

\section{(Q) OpenEdition}

\section{Journals}

Electronic version

URL: https://journals.openedition.org/remi/6147

DOI: $10.4000 /$ remi.6147

ISSN: $1777-5418$

\section{Publisher}

Université de Poitiers

\section{Printed version}

Date of publication: 1 December 2012

Number of pages: 127-143

ISBN: 979-10-90426-06-1

ISSN: 0765-0752

\section{Electronic reference}

Catherine Guéguen, "New Migrants from Continental China in Philippine Cities: Differences in Profiles and Settlements", Revue européenne des migrations internationales [Online], vol. 28 - n4 | 2012, Online since 01 December 2015, connection on 14 April 2022. URL: http://journals.openedition.org/remi/ 6147 ; DOI: https://doi.org/10.4000/remi.6147 


\section{New Migrants from Continental China in Philippine Cities: Differences in Profiles and Settlements}

\section{Catherine Guéguen ${ }^{1}$}

Many studies in various fields were established on the Chinese community in the Philippines: from a historical angle with Amyot (1972a and 1972b) and Wickberg (1998a and 1998b), from a sociological and anthropological perspective with See (1988) and Ang See (1997, 2000, 2004 and 2005). Those productions together with general studies on the overseas Chinese communities in South East Asia, on Philippine economy and the urban environment allow us to tackle the context of our topic.

These new migrants from Mainland China can actually be defined by comparison with the Chinese populations that have been settled in the Philippine archipelago for a long time. Due to their short stay, those migrants don't have any mental, family or spatial landmarks in the Philippines. There's another striking difference with the previous migration waves of the 1930s: migrants no longer leave their homeland alone but are generally accompanied with their relatives.

The close family circle is present, yet the forebears stayed behind in their home province. For most of them, settling down for good in the archipelago is out of question, but they nonetheless try to thrive within a short period of time. Philippine cities seem to be an Eldorado for those migrants (an estimated 60,000 individuals). The analysis of those migrant's profiles also takes into account that of the local Chinese community: the mostly used statistical data estimate the Sino-Philippine community at about 800,000 people, among whom, according to the figures extracted from the National Statistics Office only around 60,000 speak Chinese.

From the Presidency of Joseph Estrada (1998-2001) on, new waves of Chinese migrants reached the Philippines. The Filipinos called themTDK: tai diok ka or GI: Genuine Intsik (pejorative word for Chinese from Mainland China in hokkien or "intsik" in tagalog). From then on, they competed with local businessmen with their "dirt cheap merchandises". Since 2003, the flexible visa procedure to travel to the Philippines was spread to Chinese citizens from Continental China. The Chinese passport holders can, like any other traveller, get a three-week-tourist

1 Géographe, chercheur associé à I'ENeC, UMR 8185, 190-198 avenue de France, 75244

Paris cedex 13 ; catherinegueguen@ hotmail.com 
visa, which can be extended, for a few thousands of pesos. The access of the Asia Region to the "Continental Chinese tourists" raises many questions, notably for the countries concerned, as regards these eased travel facilities, but above all the residence of those new migrants' populations.

The cities are the main places for those migrants to settle down. Thus we may wonder what the spatial integration opportunities are for those migrants and what social links emerge from the latter. Without any doubt, the presence of a long established Chinese local community has been assisting them in their integration process, even for a short stay of a couple of months. However some migrants have been living in the Philippines since the early 1990s and a more diversified professional integration has now broken the tradition of the Chinese community specialized in trade.

A city is a key place to observe and understand the social link structures, which permit and continue today's Chinese migrations towards the Philippines. Nevertheless many differences can be noted in the professional profiles of those migrants, their being visible or not within the city, as well as for the human or cultural impacts on the local Chinese community.

\section{Migrate to the Philippines from Mainland China}

\section{From Regional to Local Scales: Migration Procedure Made Easier}

Since 2003, like any other citizen part of the Association of the South East Asian nations, Chinese get a three-week-tourist visa when they arrive in one of the three international airports in the Philippines (Manila, Cebu and Davao) (Map 1). First, air traffic has intensified between Manila and Xiamen, the main gate for Southern China, via Hong Kong. Moreover, air transport is more and more frequent and also cheaper. There are numerous "low cost" services between South China and the Philippines. Those companies also intensify plane traffic between Singapore and Cebu or Davao. Eventually, affordable plane tickets and visa facilities enable Chinese citizen to travel easily in South East Asia.

However, there's no information indicating an organisation of an illegal migrant networks from Fujian to the Philippines since Continental Chinese can legally spend three weeks or more (a 59-day-visa can be issued in the Philippine consulate abroad) if they travel with a plane return ticket. They are actually regarded as being "clandestine" as soon as they no longer pay for the visa extension fees. This procedure must be dealt with in the main immigration Bureau in Manila, in the inner city district, as well as in the two offices located in province that is Cebu in the Visayas and La Union in Northern Luzon. Relying on the counting up of arrivals and departures, the immigration Bureau reckons there are 100,000 illegal people from Mainland China. On the other hand the Chinese Authorities estimate that over a period of 10 years 45,154 people left Fujian for economical reasons, but no precision concerning their final destination is provided. In fact these figures are purely indicative and cannot be compared with. Another reason accounting for the illegal status of many migrants is the corruption of many government employees. 


\section{Economic Migrants Helped by Chinese-Filipinos}

Some migrations can be regarded as "economic" inasmuch as the migrant comes from a poorer area than the land of welcome. Those migrations take a special emphasis in the Philippines capital city. Indeed, when Chinese-Filipinos visit their hometowns or cities in Fujian, clannish networks are reactivated and "services" are asked to the visitors. The candidate for migration can leave with his "tutor" who will carry out for him or her a few administrative procedures. The first one starts as early as at the airport since Philippine migration forms to enter the country are only written in Roman characters, the latter being only written and read by a mainlander. Those migrations can be qualified as "tutorial" because the Chinese-Filipino leaves Fujian with his favourite.

Later on, the Chinese-Filipino will help him to find a first occupation in Manila, or the newcomer may even be employed in his business or sent to province to be hired in a friend's company. Those "person to person" migrations are evidence for the clannish links established with the homeland. The "discovery trip" is another way to migrate to Manila. Small groups of Fujian tourists can be seen in Binondo guided by a mainlander. They are both accommodated in a cheap hotel in Ongpin Street or in its neighbourhoods.

But the profiles of those migrants are different. They are now obliged to reactivate the old clannish structures through old clan associations instead of the Philippine official networks. The activities of those small businesses are in general close to illegality even though they have to abide by local laws and pay taxes for trading activities. Small shopkeepers are forced to get in touch with Chinese Filipinos who set up the urban market zone in northern Manila.

The ethnic origin of the new migrants is almost unique. Most of them come from Fujian (Xiamen and its surroundings) and work as shopkeepers in the numerous market areas of the capital city and particularly in the downtown areas which most of the time correspond to the Chinese district (Alip, 1993: 16-23). Those small traders meet the local demands based on cheap manufactured items (textiles, plastic utensils, small electric machines, and so on). All those products are imported from Continental China. Most of those new migrants don't have long-term project in Philippines cities.

\section{Professionals in Business or in Culture Hired by the Local Chinese Community}

The evolution of the portrait of the local Chinese community in Manila implies new professional inputs from Continental China. Many educative policies have considerably reduced the amount of teaching in Chinese language and cultural topics in the so-called Chinese Schools especially since the 1970s, with the policy of Filipinization implemented in the school curriculum during the Marcos era. With time, the skills in Chinese language of the younger Chinese Filpinos generation have lessened; for example the younger ones can hardly both write and speak Chinese.

The changes in the community and also in the components of the close family are responsible for this lack of Chinese culture transmission. Grandparents no longer stay with the extended family as they used to 40 years ago, which implies 
that the younger ones no longer have permanent Chinese speaking adults at home, especially when the parents work as businessmen as they usually resort to Philippine nannies to take care of their offspring. The children first speak Tagalog (the Luzon language) and English before learning the Chinese language which they will be taught in the Chinese schools. That's why Chinese teachers are very much needed. For a couple of years the latter have been hired by parents associations. Before, most of the Chinese teachers were hired in Taiwan. Since the 1990s some schools directly resort to the Chinese overseas affairs Bureau in Continental China, which usually sends young trainee teachers for a one-yearcontract.

Investors from Continental China use the official procedure. Thus the Philippine Officials had endeavoured to canalize those wealthy businessmen (coming from Taiwan or Mainland) offering them offices in the "State building" in Juan Luna Street, in the heart of Binondo. In fact, only the holders of an investor visa enjoy a clear situation regarding their residence permit in the Philippines since they had to pay more than US\$50,000 for it $(€ 35,000)$.

The profile of the few migrants from Guangzhou is different. This small community attracts professionals in the education area through the Chinese Overseas Affairs Bureau. The Manila Patriotic High School is the only one to offer a curriculum in the three Chinese languages: Cantonese, Fukkenese and Mandarin.

There are few variations in the profile of the new migrants in provincial cities. There are less numerous and usually settled down in Cebu or Davao after a stay in Manila. Signs of lasting settling are visible within these provincial Chinese communities. They are shopkeepers too and a few schools can afford to enrol teachers from mainland China, a few of which are connected with the "Amity Club" and welcome trainee teachers from mainland. As a matter of fact, after Ferdinand Marcos acknowledged the Popular Republic of China in 1975, then the latter encouraged members of the local Chinese community to create an organization in charge of the revival of cultural and economic links with Continental China through the Amity Club, while the Chinese Chamber of Commerce was more oriented towards Taiwan (See, 1988: 319-334).

The new migrants don't necessarily come from Guangzhou or Fujian anymore, some come from Northern China but use the same networks to facilitate their integration. Then, new migrants from Northern China can be seen in market areas in cities especially in the provinces where they occupied commercial stalls in General Santos in Southern Mindanao.

These population flows are generated by the different conditions and needs that can be found in the departure or arrival area. Migrants from Fujian are attracted by the Philippine archipelago, as were their ancestors a couple of decades ago. They take advantage of the improvement of air traffic and of the fact that residence procedures on arrival are made easier. Yet other reasons are also mentioned: business facilities and the demography restriction. A really small portion of them works in the cultural or teaching fields. What's more Chinese migrants have different impacts in term of visibility: newcomers involved in trade are easily located; as for the others they are almost invisible. This aspect has to be considered and various patterns will be completed. 
Map 1: The notable Chinese settlements in Philippine cities

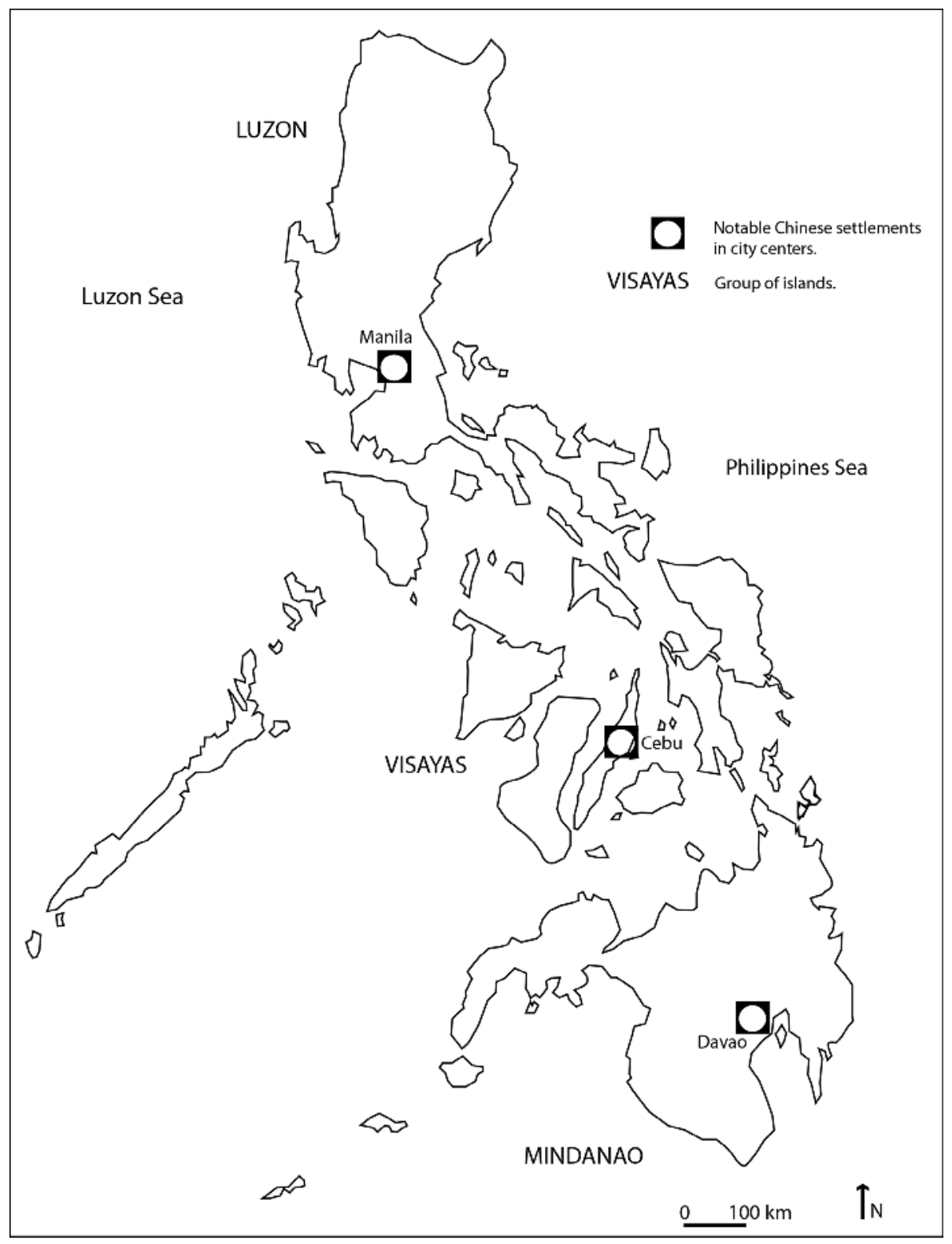

Source: C. Guéguen, April 2012. 


\section{Chinese Migrations more or less visible in the Urban Landscape}

For ever, the Chinese district can be compared with an "integration gate" for every new Chinese migrant whatever his or her background. The urban expansion of cities also induces the spreading of new migrants. Chinese Filipinos take part in the latter's economic and spatial integration. They are more present in Binondo, the heart of the old Chinese district, than in any other place, but can also be found in suburban residential areas. The Chinese district offers many opportunities, but those new migrants entail competition and adaptation within the area.

\section{Migrants hired by local Chinese community melting in the previous urban infrastructures}

Migrants hired for their linguistic skills in Chinese are very few and generally get a short time working contract (one year), which includes housing nearby the school in the suburbs or in the old Chinese district. For example, the Chinese teachers in Grace Christian High School located in Quezon City live in residential units like Damar village or Grace village in the neighbourhood of the school like most of the students' families (Guéguen, 2008b: 85-87). They are hired through the initiative of the parents' board. Cooks and typographers recruited by the Chinese newspapers in Manila also live close to their working place.

The residential areas where the Chinese Filipinos dwell are mostly gated communities which allow small size companies (packing, handcraft, trade office). New migrants could work there as manpower, especially in the northern district of Manila (Malabon, Quezon City). They are discreet since warehouses or small companies are not easily accessible with wire fencing and guards who block any intruder. Many of them are involved in "repacking activities". In fact items, which arrived in Manila piers and are, re-packed in smaller packages, adapted to the Philippine market.

\section{New Commercial Units for the New Migrants}

Economic migrants are more numerous and need specific reception commercial units. It's in the heart of the old downtown of Manila, in the Divisoria market zone, that urban changes are the most visible. This area is accessible through all kinds of public transport and several new commercial centres provide stores to the new comers.

Originally, some of them were not meant to welcome these migrants but due to the lack of vacant commercial stalls, the latter were given the opportunity to open a stall in older commercial structures in the area. One of the most ancient is the Tutuban Centre: the former Railway station of the district transformed into a mall, which comprises a few buildings along CM Recto Avenue. This commercial centre is managed by a Chinese Filipino estate company, which opened in 1992. Customers are attracted by the numerous parking spaces but most of the clients arrive through popular public transport (kalesa, jeepney, tricycle, pedicab and since 2008 with the aerial Light Railway Transport). In spite of its attractiveness, $25 \%$ of the commercial area remains vacant for two reasons. On the one hand, the competition has been really high for two years along CM Recto Avenue with 
Map 2: A specific visibility for the new Chinese migrants in the old Manila Chinese district: Binondo

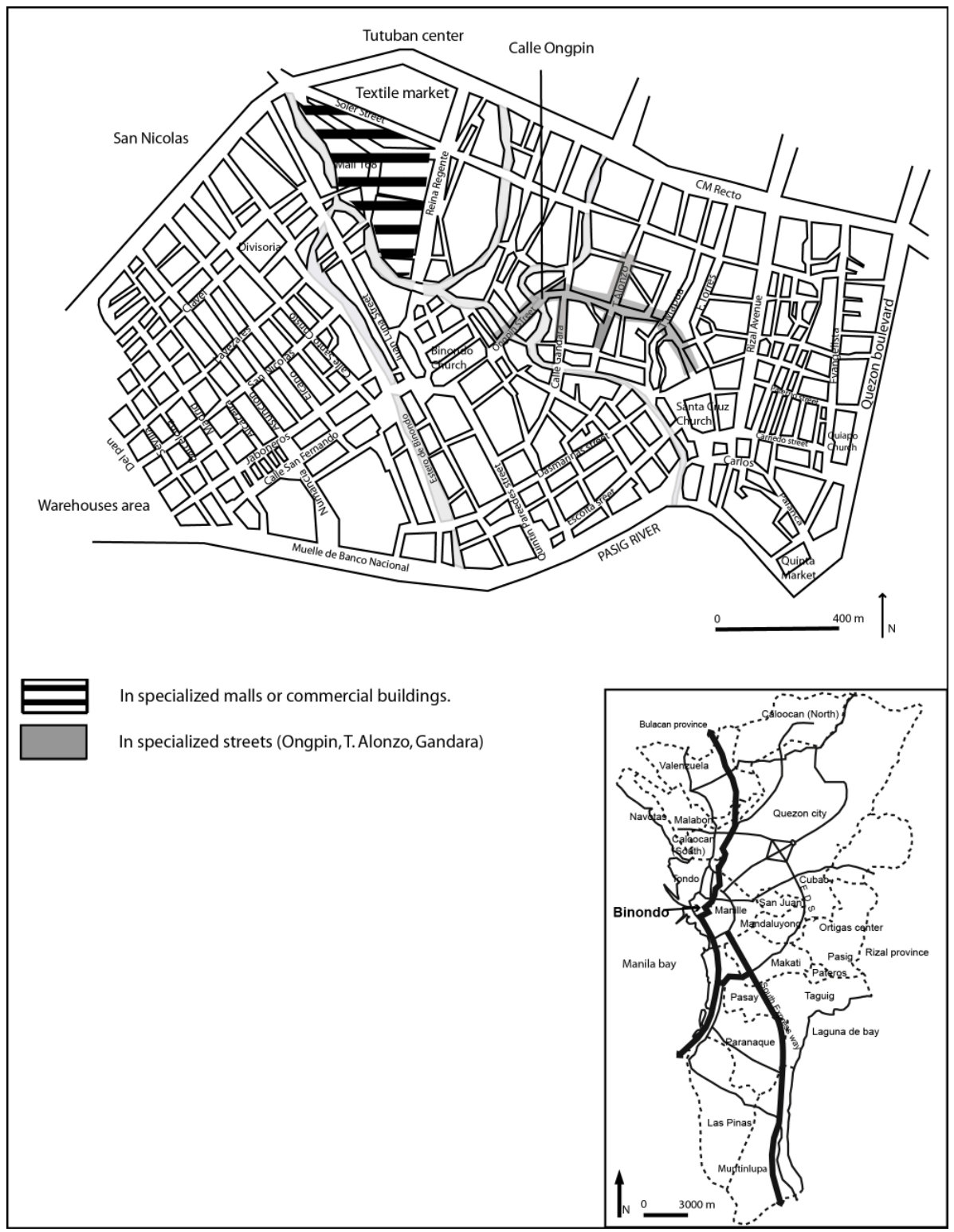

Sources: Manila City Hall, field work, August 2011 and C. Guéguen, April 2012. 
the building of new commercial malls that are in fact more attractive than the older ones and on the other hand, some stalls to rent are not properly located and are far from walking alleys or doors.

To take another example, the new Divisoria mall was built on a public property owned by the City Hall of Manila. The surroundings of this commercial mall are really congested by traffic: small trucks constantly shuttle in the area to supply the market, located in the basement, with fresh produce. The site also has a bad image due to the numerous pickpockets. The rental decreases slowly but a lot of stalls already are empty.

The implantation of the "mall 168" is carried out in the close surrounding of the area of the Divisoria market: south of Recto Avenue and east of the current Divisoria market, which opened in 2004. What's more, rumors concerning the project have been multiplying: it is said to have been built by Taiwanese investors. Yet these rumours are not grounded since the centre is actually owned by a Chinese Filipino real estate firm (formerly involved in textile business in the Divisoria district). This mall is at the same time an example of urban rehabilitation of a degraded urban area and an adaptation to a growing demand in commercial units expressed by the new comers from Mainland China. This commercial structure is composed of three floors, the two first levels display manufactured items (textile, shoes, bags, etc.), and the third one comprises a food court where stalls offer cheap fast food to its customers. In Mall 168, 40\% of the shopkeepers import merchandises directly from China (Guéguen, 2008a: 544-546).

Wholesalers from the provinces or small shopkeepers in the provinces or in Metro-Manila, even individuals are used to shopping in Mall 168. Renting a stall there ranges from 25,000 pesos to 50,000 pesos (from 415 to 830 euros ( 1 euro $=60$ pesos/rate for 2012) a month (a stall of a few square meters and a storage place located in the ceiling). It can be rented for 25 years. From Monday to Thursday, 7,000 to 8,000 persons daily visit this commercial centre, but 12,000 to 15,000 pass through it over the weekend even though its parking area only offers 200 spaces (no extension is possible on account of the high cost of land).

In provincial cities like Cebu and Davao, situations are quite different. In Davao, the Chinese community increases, as does the city. In almost 20 years, between 1980 to 1999, the total population of Davao has doubled to reach 1.5 million inhabitants. The new comers from Mainland China were canalized and they now occupy stalls in commercial centres created for them on the model of the Mall 168 in Manila. These centres also have very evocative names and are supposed to bring luck: 668 Plaza in Monteverde Street for example. The arrival of those migrants seems to have been canalized from Manila. Indeed, associations connected with the "Amity Club" are said to orientate them towards this part of the Davao Chinese district. In Davao, new migrants are also shopkeepers in the old downtown of the city in San Pedro Street.

In Cebu, Chinese migrants contribute to the revival of the bodega system: the old warehouses are used as storage places. The newcomers settle as shopkeepers near local Chinese family businesses dealing grains or rice in the pier area. Migrants are involved in cheap manufactured trade. A similar project to that of 
Mall 168 was set up a few months ago, but has failed. Migrants should have been welcomed in this former department store, totally newly disposed for them. The area of the Mango square and the former Rustan department store were transformed in 868 Wholesale centre, but in spite of its favourable location on the main transport axes of the city, this commercial structure doesn't attract tenants. For the time being, the centre remains almost empty.

\section{Specialized Streets and Boutique Sharing}

Manila offers many kinds of commercial integration dedicated to the new migrants from Mainland China, even in the specialized streets inside the Chinese district. Ongpin Street is an interesting case study due to its specialization in the gold trade. Many Chinese Filipinos are shopkeepers. Since the 1980s the Gold trade has been developing in parallel with the Philippine workers migrations (called Balikbayan). Indeed, the money earned abroad was often invested in gold. More recently, old shophouses have been transformed in commercial centres for gold (for about 10 years). The first of this kind was erected in Plaza Santa Cruz and the most recent opened around 2006. Most of the tenants of those commercial stalls are mainlanders from Fujian. So far those commercial structures have been quite unsuccessful: over a period of six months, from February 2008 to August 2008, many stalls remained empty. It seems that balikbayan families no longer invest as much as before in gold.

In Ongpin Street, some stores are arranged in two separate commercial units: there is no wall to separate the shop but two counters involve significant boundaries. The Chinese Filipino lessee had to resolve to share his or her boutique since he or she cannot afford to pay for the whole rent. The new migrants from Fujian are the second occupants of the shop and all sell DVD's, shoes or any items of general merchandise. As for the Chinese Filipino, he is still involved in his or her traditional activity, such as jewellery. The harmony between the two shopkeepers is often far from being cordial.

The migrants work in some commercial spaces or networks that are less valued by the Chinese Filipinos but are excluded from certain economical fields as well as from certain streets. Moreover, the spatial integration of those migrants is different from one migration wave to the other. The Fukkien are the most numerous and are involved in a similar kind of activities. They are also more visible since they gather in selected parts of the Chinese districts.

Most of the time the migrants hired in Mainland China speak several languages and are integrated in the districts that are mostly occupied by the Chinese Filipinos inside Binondo or in suburban areas. The working agreement includes accommodation in the school vicinity; thus they can be found in any part of the city since Chinese schools can be situated in any part of Metro-Manila.

As for the Chinese investors, they often stay in the heart of the Chinese district, and their apartment also often serves as their office. The latter can choose to settle down in the other business areas of the city like Makati or Ortigas in Mandaluyong City. 


\title{
Social Contacts between Communities Involve an Economic Integration but Cultural Bridges are Selective and Limited
}

\author{
City Centres Recaptured by New Migrants from \\ Continental China
}

Since the 1960s, downtowns in large Philippine cities have been abandoned little by little for Manila and since the 1980s for big cities in the provinces; ex-urbanization generated the construction of massive buildings (condominiums) and residential areas exclusively dedicated to single detached houses areas.

Then the city centres were progressively taken over by poor populations, which have intensified the creation of slums and the progressive decrease of activities like movie theatres and trade. The market areas in these old districts near the pier are the main places to settle for the new migrants. Thanks to the help of associations, a fellow-countryman, or the Chinese Chamber of Commerce, the new comer would be able to open a shop in any vacant space. They employ Filipino sales ladies and gradually communicate with their employees in a basic Tagalog or Cebuano, languages that they did not speak when they arrived and that are mostly practiced in the Visayas and Mindanao. New migrants are canalized towards those commercial units, which provide them with real flexible conditions in terms of investment and rental. Those commercial centres provide rental conditions, which are not strict for anyone interested in a shop keeping activity. Rental costs fell down significantly a couple of years ago, new rental contracts take into account the short stay of the new comers in Manila or in big provincial cities. The offer in commercial units is quite high and competition entailed a reduction of the rental fees to attract them.

Local public authorities also take part in the coming of these migrants. All the shops they rent have to be checked by the City Hall: opening a shop implies to pay a tax to the local authority. For example the Manila City Hall delivers a plaque to certify the legal trade activity; this one is visible in any shop of Manila. The Manila City Hall has another major role in the coming of these migrants as it provides public lands for lease under a "concession contract"; this is the case for the new Divisoria Mall which has obtained a 25-year-concession contract. This local authority also allowed the construction of the Meisic Mall on a public land, which implied the reduction of the playground in Jose Abad Santos High School perimeter (Guéguen, 2008a: 533-554).

The Chinese from Mainland revive the "Bodega system" and bring about a gentrification phenomenon in old downtowns. As a matter of fact, the growing supply of stalls in new commercial malls has attracted many shopkeepers who had, up to then, been working in rundown stands and thus decided to move. Many of those old shops were transformed into storage areas (bodegas) for nonperishable goods such as textile, or dry vegetables (pulses, cereals). A few are rented to newcomers, especially those located along CM Recto Avenue. In the heart of Binondo, part of the district has been deserted by commercial activities and become more residential. That's why shop houses are turned into new small buildings or can be gathered to form a bigger space, which is necessary to build a condominium. 
In Cebu and Davao, the new migrants are next to the old trader families in the city centres where activities are different and much less diversified. Old warehouses are also used there as storage areas, but also to pack products for the retail market.

In old Manila, residential buildings or estate projects have been flourishing in the Chinese district. Several brand new residential condominiums are being built in Ongpin Street and its surroundings. The estate companies involved in these projects are the biggest Chinese Filipino firms (Krinks, 2002: 198-201), namely Megaworld owned by the tycoon Andrew L. Tan. Housing also became part of the strategy of the 168 companies that already offered commercial spaces. Buildings of all sizes and kinds are multiplying. The process is simple: once an estate company has bought several plots and succeeded in regrouping them, an opportunity to build a structure which can combine residential and offices spaces to be bought or rented arises. As for private individuals, they rebuild on their property a small building made up of four to five floors which meant to accommodate the family, yet, a vacant apartment can also be let. The presence of the new migrants leads to the building of residential units. They are willing to stay in the Chinese district since they are familiar with this area full of landmarks, notably with the language, cuisine or Chinese items but it is above all within walking distance to their shop.

Those "middle class" families are looking for elements included in the westernized society of consumption which they could find in Mainland China, fast food restaurants, coffee shops with an open air areas for example. These elements attest for the evolution of the resident population and the impacts they have in this traditional Chinese district.

Populations in Binondo are different. The Chinese population settled in the Philippines shows multiple aspects and the waves from Continental China contribute to its plurality although they are often regarded as "foreigners" or troublemakers in the local business sector. Their presence is not insignificant: those migrants are canalized by commercial structures and the authorities' leniency towards them.

Migrants generate competition in trade and enterprise sectors. These new commercial malls impact a lot in the neighbourhood of Divisoria. Thanks to them the district regains prestige. These private initiatives in renovation are encouraged by local authority units (City Halls and barangay). For example, many actions focus on the management and cleaning of roads. For these reasons, a new square was created in front of Binondo Church, which brings new activities and shops in this former degraded area.

\section{New Interactions between Communities Thanks to the Chinese Language}

The arrival of migrants accompanied by families strengthens educative and language activities oriented towards Continental China like institutions in charge of spreading the Chinese culture that is schools and newspapers. The arrival of these migrants who are seeking special services they can hardly be provided with boosts the hiring of Continental Chinese since the local Chinese community can hardly write Chinese. Those working for newspapers as typo- 
graphers or proofreaders, Chinese language teachers in Chinese schools, and assistants in various associations all come from Mainland China. Without this population that can write and speak Chinese, the education system in Chinese schools cannot be achieved properly. Teaching the Chinese language is an issue for the school heads. It is indeed very difficult to find skilled teachers on a local scale. Most schools resort to the Overseas affairs Bureau to provide teachers or even volunteers. Thus young Chinese teachers come to the Philippines for one or two years. In Cebu, a kind of transition appears. In the Samanthabadra Institute, a Buddhist school affiliated with the Chinese Filipino schools in the Philippines Association, hired a young female teacher born in China but brought up in the Philippines by her parents who had arrived as "newcomers" in the nineties. On account of her background and education she can teach English, Tagalog and Chinese, which is in fact her mother tongue. Her parents left Fujian in the middle of the 1990s and stayed for a while in Manila, then migrated to Cebu City where her father is still a shopkeeper (Interview made in Cebu, august 2008). This example shows the long process of integration and the transition in work category: within the younger ones who, having been trained in the Philippines can have access to different working sectors. It also shows the asset it presents to stay in the Philippines to acquire skills in English or education.

Besides the necessity to hire professional staff to keep up with the Chinese language outside the Philippines, the solidarity links through clan or Chinese chamber associations remain present. The input of new comers implies multiple adaptations in the action of the traditional associations. For example, old members of the Pasay Chinese Chamber of Commerce whose office is located within the Pasay Chung Hua Academy, provide support lessons in Tagalog. Almost all the lessons are taught in this language. This action shows how the relations between the old and new waves of migrants have evolved. Integration passes through an intergeneration support. In Davao, new and older Chinese associations are involved in a common cultural project that is the materialization of a Chinatown by the construction of Arches, and use of Chinese characters coupled with roman letters on signs boards.

\section{New Chinese Migrants Linked to Illegal Activities}

Moreover, the fact that some Chinese leave their homeland to settle down in the Philippines brings about many questions regarding the economic situation in the country they left, their arrival brings about changes in overseas Chinese communities. On a practical level, the migration waves entail a bad image of Continental China in Chinese communities overseas (Ang See, 2007: 116). This migration wave gives rise to another generation of Chinese born outside the Philippines and implies a new integration process; yet cultural bridges are far from being clear.

The local Chinese community worries about the wrongdoings and illegal activities committed by a few migrants as they tarnish the image of the whole community. Since the beginning of the year 2005, the number of tourists from Mainland China has been increasing by $150 \%$. According to the Department of Tourism more than 46,000 persons would have arrived in the Philippines in the last semester of 2005, they were only 17,000 in 2004 for the same period. The Philippine Tourist Office aims at attracting more English speaking Chinese with a western way of life from Beijing and Southern China. The important arrival 
of these tourists is linked to the tourist visa they can now easily get when they arrive in Manila, Cebu or Davao. But some of them don't have the profile of the perfect international tourist. The Chinese-Filipino newspaper Tulay quotes in its July $19^{\text {th }} 2005$ edition the apprehension of eight Chinese tourists involved in illegal sales activities. They were arrested in their stalls located in the Baclaran Mall in Paranaque by the immigration officers after their Filipino employees had complained about their working conditions. Following this arrest their status as immigrants was checked.

The media also largely voices the crimes committed by Chinese businessmen notably as regards the working conditions. Some of their employees are said to be sequestered or held as slaves in warehouses or manufactures in the northern part of Manila. These facts impact on the complete Chinese community. Certified illegal traffics are settled by continental Chinese with the complicity of Chinese Filipinos. For example, a Chinese from Quezon City was apprehended for using his house as a storage area for drugs, he and his brother had taken on false family names sounding Filipino (Ben and Wally Chua). Arrest areas and drugs dealings places are numerous. The apprehension can be carried out anywhere. Once a Chinese was arrested in his hotel room in the Malate district where he had organised an illegal laboratory to prepare ketamine in a big saucepan. The thick smoke coming from the window had attracted the attention of police patrol (in Tulay, April $5^{\text {th }}$ and August $2^{\text {nd }}$ 2005). Such actions have consequences on the entire Chinese community, part of which fights to break this image associated to crime and corruption.

\section{Conclusion}

Cities allow an analysis of the reconstitution of the Overseas Chinese community and also reveal the existence of old networks inherited from the Marcos era or simply through the revival of traditional networks (clan and Chambers of commerce). The arrival of those migrants translates two goals which both answer to the needs of the local populations. They are hired to serve the overseas Chinese population so as to maintain the Chinese culture and especially language skills and to answer the needs of the mainly poor Philippine population.

The massive arrival of these migrants contributes to the renewal of the local Chinese community but also contributes to the dual portrait of the Chinese districts: wealthy thriving thanks to trade but these districts also represent places for multiple illegal activities which are emphasized by the presence of this newly arrived "floating" migrant population that are, most of the time, dependent on the local clan network.

The specialization of these new migrants in low cost manufactured items imported from Continental China disturbs many sectors in sale, small and medium companies mostly owned by Chinese Filipino businessmen. Hereafter, their workshops located in the northern part of the city have progressively shut down. In Quezon City, residential areas dedicated to the local Chinese population are surrounded by industrial fallow land as local entrepreneurs can no longer compete with the cheap prices of the goods imported from China. These businessmen were obliged to transform their business in a trade company and now import goods from Mainland China to insure their survival. 


\section{References}

Abinales Patricio and Amoroso Donna (2005) State and society in the Philippines, Lanham-Maryland, Rowmann \& Littlefield Publishers, 353 p.

Alip Euphrenio (1993) The Chinese in Manila, Manila, National historical Institute, $71 \mathrm{p}$.

Amyot Jacques (1972a) The Manila Chinese, Manila, Ateneo de Manila, 170 p.

Amyot Jacques (1972b) The Chinese and the national integration in Southeast Asia, turngraph series $n^{\circ} 2$, Institute of Asian studies, Faculty of Political Science, Chukalongkorn University, 108 p.

Ang See Teresita (2005) Tsinoy, the story of the Chinese in Philippine life, Manila, Kaisa para sa kaunlaran Inc., 267 p.

Ang See Teresita (2004) Chinese in the Philippines, problems and perspectives, vol. III, Manila, Kaisa para sa kaunlaran Inc., 219 p.

Ang See Teresita (2000) Intercultural relations, cultural transformation and identity, the ethnic Chinese, selected papers presented at the 1998 ISSCO conference, Manila, Kaisa para sa kaunlaran Inc., 627 p.

Ang See Teresita (1995) The Chinese in the Philippines: continuity and change, in Leo Suryadinata Ed., Southeast Asian Chinese, the socio-cultural dimension, Singapore, Times Academic press, pp. 28-41.

Ang See Teresita and Go Bon Juan (1994) The ethnic Chinese, proceedings of the international conference on Changing Identities and relations in Southeast Asia, Manila, Kaisa para sa kaunlaran Inc., 249 p.

Auvray Stéphane, Jimenez-Halare Christina et Galang Roberto (2003) Élites et développement aux Philippines : un pari perdu ? Paris, Publication de I'IRASEC/ Les Indes savantes, 315 p.

Baffie Jean et Huetz de Lemps Xavier (2001) Manila, Metro Manila, une introduction bibliographique, Moussons, 2, pp. 83-98.

Courtine Philippe (2001) La restructuration d'un espace urbain du sud-est asiatique : la Chinatown de Bangkok-Thaïlande, Les Cahiers d'Outre-Mer, 214, pp. 137-156.

Dannhaeuser Norbert (2004) Chinese traders in a Philippine town: From Daily Competition to Urban Transformation, Quezon City, Ateneo de Manila University Press, $264 \mathrm{p}$.

Felix Alfonso (Ed.) (1969) The Chinese in the Philippines, vol. II (1770-1898), Historical Conservation society, Manila, Solidaridad Publishing House, 252 p.

Guéguen Catherine (2007) Les Chinois de Manille : ancrages et évolutions sociospatiales, Thèse de doctorat en géographie, Paris IV-Sorbonne, 392 p.

Guéguen Catherine (2008a) La zone de marché de Divisoria transformée par les nouveaux migrants de Chine continentale, Les Cahiers d'Outre-Mer, 244, pp. 533-554.

Guéguen Catherine (2008b) Les Chinois de Quezon City : quelle intégration dans le cadre urbain de Metro-Manila ?, in Christian Huetz de Lemps et Olivier Sevin Éds., L'Asie-Pacifique des crises et des violences, Paris, PUPS, pp. 79-92. 
Huetz de Lemps Xavier (1994) Manille au XIXe siècle, croissance et aménagement d'une ville coloniale (1815-1898), Tome 1, Thèse de Doctorat d'histoire, Université Michel de Montaigne- Bordeaux III, 406 p.

Krinks Peter (2002) The economy of the Philippines: elites, inequalities and economic restructuring, London, Routledge, $280 \mathrm{p}$.

Ma Mung Emmanuel (2000) La diaspora chinoise, Gap, Ophrys, 175 p.

Nonini Donald M. (2001) Diaspora Chinese in the Asia-Pacific: transnational practices and structured inequalities, in Armstrong M. Jocelyn et al., Chinese populations in contemporary southeast-asian societies. Indentities, interdependence and international influence, London, Curzon, pp. 237-263.

Salmon-Lombard Claudine (1969) La communauté chinoise de Makassar : vie religieuse, in T'oung Pao, 55, pp. 242-297.

See Chinben (1988) Chinese organizations and ethnic identity in the Philippines, in Cushman J. and Wang Gungwu Eds., Changing identities of the Southeast Asian Chinese since the World War II, Hong Kong, Hong Kong University Press, pp. 319-334.

Suryadinata Leo (Ed.) (1997) Southeast Asian Chinese, the socio-cultural dimension, Singapore, Times Academic Press, 262 p.

Yap Luisa (1998) Les Chinois des Philippines, Perspectives chinoises, 49, pp. 56-59.

Wickberg Edgar (1998a) The Chinese in the Philippines, in The encyclopedia of the Chinese overseas, Singapour, Archipelago Press and Landmark Books, pp. 187-199.

Wickberg Edgar (1998b) Chinese organizations in Philippine Cities since the second world war: the case of Manila, in Wang Ling-Chi and Wang Gungwu Eds., The Chinese diaspora selected essays, vol. I, Singapour, Times Academic Press, pp. 224-251. 


\section{Catherine Guéguen}

\section{New Migrants from Continental China in Philippine Cities: Differences in Profiles and Settlements}

In the 1990's, the number of migrants from Mainland China increases in the Philippines archipelago. The phenomenon cannot be evaluated precisely (figure between 60,000 and 100,000 persons) but remains important in this local Chinese community whose total population is between 800,000 and one million. Most of those new comers are from Fujian province, which is also the motherland of more than $90 \%$ of the local Chinese community. Most of them embrace the Filipino citizenship. The city is the main study site to analyze the multiple impacts and social links between new comers and local Chinese residents. The presence of new comers is particularly readable in old Chinese districts in cities like Davao, Cebu and Manila. They also settle in suburban areas, it shows the different professional skills among the migrants. Part of the new migrants from continental China answer the needs of a local poor population; the other ones complete the lacks of the local Chinese community in quest of "genuine Chinese culture" mostly based on the practice of the Chinese language. All of them contribute to the renewal of the local Chinese community.

\section{Les nouveaux migrants de Chine continentale dans les villes philippines : profils et ancrages différenciés}

Les années 1990 ont vu un accroissement des migrations de Chinois du continent vers les Philippines, le phénomène n'est pas évalué précisément (entre 60000 et 100 000) alors que la communauté d'origine chinoise dans l'archipel serait comprise entre 800000 et un million d'individus. Ces migrants sont majoritairement du Fujian, province dont sont originaires plus de $90 \%$ de la communauté chinoise de l'archipel, laquelle a opté massivement pour la nationalité philippine. La ville constitue un terrain d'étude privilégié pour analyser les impacts et les liens sociaux de ces nouveaux migrants avec les communautés chinoises locales. La lisibilité urbaine de ces nouveaux migrants est flagrante dans les vieux quartiers chinois de villes comme Davao, Cebu ou Manille, mais ils sont aussi présents dans les espaces périurbains, ce qui démontre la variété du profil de ces migrants de Chine continentale. Ces migrants, pour une partie d'entre eux, répondent aux besoins d'une population philippine pauvre, les autres pallient les manques d'une communauté chinoise outre-mer en quête de " culture chinoise originelle " essentiellement basée sur l'usage de la langue chinoise. Tous contribuent à la recomposition de la communauté chinoise implantée aux Philippines. 


\section{Los nuevos migrantes de la China continental en las ciudades filipinas: diversidad de perfiles y asentamientos}

En los años 1990 se vio un incremento de la migración de los chinos del continente hacia Filipinas, el fenómeno no ha sido evaluado con precisión (entre 60000 y 100000 ) aunque la comunidad de origen chino en el archipiélago comprendería entre 800000 y un millón de individuos. Estos migrantes son en su mayoría de Fujian, provincia de la cual provienen más del $90 \%$ de la comunidad china del archipiélago, y que ha optado de forma masiva por la nacionalidad filipina. La ciudad constituye un terreno de estudio privilegiado para analizar el impacto y los vínculos sociales de estos nuevos migrantes con las comunidades chinas locales. La legibilidad urbana de estos nuevos migrantes es incuestionable en los antiguos barrios chinos de ciudades como Davao, Cebú o Manila, pero están también presentes en los espacios periféricos, lo que demuestra la variedad del perfil de estos migrantes de la China continental. Una parte de estos migrantes responden a las necesidades de una población filipina pobre, la otra parte palía las carencias de una comunidad china de ultramar en busca de "la cultura china original" basada esencialmente en el uso de la lengua china. Todos ellos contribuyen a la restructuración de la comunidad china instaurada en Filipinas. 